\title{
MINAT BACA PADA PSIKOLOGIS SISWA KELAS 1 SEKOLAH DASAR (SD) 01 KECAMATAN LIMA KAUM KABUPATEN TANAH DATAR
}

\author{
Desnawita, Desni Yulinda \\ Pustakawan Perpustakaan IAIN Batusangkar \\ Balai Labuah Bawah Jln. Mesjid Raya Kabupaten Tanah Datar
}

\begin{abstract}
This study aims to describe the reading interest of elementary school students 01 and the factors that influence the reading interest of elementary school 01. This research is a descriptive study with a qualitative approach. The subjects of this study were elementary school students 01. Data collection was carried out using the methods of observation, interviews, and documentation. Interest in reading elementary school students is still low. Based on the results of the study concluded that: reading interest of elementary school students 01 is still low. Judging from the level of student visits to the library that are rarely done. Students prefer to be in class, tell stories with friends, compared to reading books to the library. The low reading interest of students is due to students lacking feelings, attention to books and the benefits of reading, as well as motivation from themselves and from others (the environment). The factors that influence students' mint reading are factors: internal factors (feelings, attention and motivation). The steps taken are by giving motivation, continuous attention to elementary school students 01 and attention to increase reading interest. Factors that influence reading interest from outside consist of the role of teacher, environment, family and facilities. A teacher should use the theory or component of learning strategies as a learning principle so that the learning process can be accepted by students well and more easily. The existence of a library in the school, where the library is a learning resource that is expected to foster interest in reading for students, then it should be managed well, for example a more attractive library design and provide many picture books that can improve the student's motor skills.
\end{abstract}

Kata kunci: Minat Baca, Siswa SD

\section{PENDAHULUAN}

$M$ inat baca merupakan factor utama untuk sumberdaya meningkatkan kualitas manusia dan upaya meningkatkan mutu pendidikan nasional. peningkatan kualitas sumber daya manusia sangat diperlukan untuk menghadapi persaian dunia pendidikan nasional dan internasional. oleh sebab itu semakin tinggi minat baca masyarakat maka semakin tinggi juga sumber daya manusia tersebut dan dapat tumbuh menjadi bangsa yang maju (Mirwan: 2016). SD 01 Merupakan salah satu SD favorit dan banyak diminati oleh masyarakat dengan akreditasi A. 


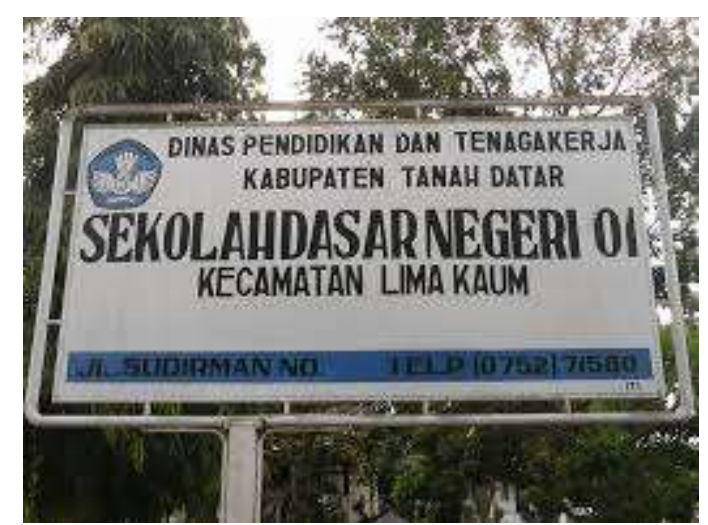

Minat membaca siswa SD 01 masih rendah dan belum efektif untuk meningkatkannya keterlibatan orang tua diyakini dapat meningkatkan minat membaca anak. Disamping keterlibatan orang tua , bacaan yang kurang memikat dan minimnya sarana prasarana SD 01 menjadi factor utama penyebab rendahnya minat baca siswa. sementara itu, sekolah tidak selalu mampu menumbuhkan kebiasaan membca bagi siswanya. sekolah belum mengoptimalkan kurikulum karena SD masih fokus tidak hanya membaca, namun kemampuan lainnya seperti berhitung, mengenal gambar. Menurut Prof. Dr. Riris K. Toha Sarumpaet, Guru besar Fakultas Ilmu Pengetahuan Budaya Universitas Indonesia ini melihat, sekolah tidak memadai sebagai tempat untuk menumbuhkan minat baca anak didik. Hal ini, menurut dia, tidak terlepas dari kurikulum pendidikan. Kurikulum yang terlalu padat membuat siswa tidak punya waktu untuk membaca. Riris mengemukakan bahwa siswa terlalu sibuk dengan pelajaran yang harus diikuti tiap hari. Belum lagi harus mengerjakan PR. (www.republika.co.id., diakses 11 Januari 2018). Oleh karena itu, solusi terbaik dalam membuka jalan pikiran seorang siswa agar mereka mempunyai wawasan yang luas, adalah dengan cara membaca. 12
Agar siswa dapat membaca buku secara ajeg, maka kepada mereka perlu disediakan bahan bacaan yang cukup koleksinya. Oleh karena itu, perpustakaan merupakan wacana baca yang mampu menyediakan beragam buku baik fiksi nonfiksi, referensi, atau nonbuku seperti majalah, koran, kaset serta alat peraga, wajib dimiliki setiap sekolah. Minat baca anak di Indonesia sangat rendah. Berdasarkan data UNESCO, persentase minat baca anak Indonesia sebesar 0,01 persen. Artinya, dari 10.000 anak bangsa, hanya satu saja yang memiliki minat baca. Hal ini disampaikan oleh Anggota Komisi $X$ DPR RI, Yayuk Basuki, dalam kunjungan di Kendal, Senin (25/5/2015).

Somadayo (2011: 7) memaparkan bahwa setiap aspek kehidupan melibatkan kegiatan membaca. Kenyataannya, minat membaca masyarakat khususnya anak sebagai pelajar saat ini masih rendah.

\section{Rendahnya Minat Baca}

Berdasarkan beberapa kajian literatur dan artikel yang diakses dari berbagai sumber, menyebutkan bahwa beberapa indikator terhadap minat baca masyarakat indonesia masih relatif rendah. beberapa data yang dijadikan bukti hasil riset tersebut adalah:

1. Badan Pusat Statistik (BPS) pada tahun 2006, yang menunjukkan bahwa masyarakat kita belum menjadikan kegiatan membaca sebagai sumber utama mendapatkan informasi. orang lebih banyak tertarik dan memilih menonton TV $(85,9 \%)$, radio $(40,3 \%)$, dan membaca koran hanya 23,5\%.

2. International Education Achiecment (IEA) melaporkan bahwa kemampuan 
membaca siswa SD di Indonesia berada pada urutan 38 dari 39 negara peserta studi, yang berarti Indonesia menempati urutan ke-38 dari 39 Negara.

3. Third International Mathematics and Science Study (TIMMS), kemampuan matematika para siswa SLTP kita berada pada urutan 34 dari 38 negara dan kemampuan IPA berada pada urutan 32 dari 38 negara. Berdasarkan data tersebut, Education for All Global Monitoring Report tahun 2005, Indonesia merupakan negara ke-8 dengan populasi buta huruf terbesar di dunia, yakni sekitar 18,4 juta orang buta huruf di Indonesia (kompas 20 Juni 2006). Rendahnya kemampuan membaca anak-anak berdampak pada kekurangmampuan mereka dalam penguasaan bidang ilmu pengetahuan dan matematika

4. Hasil Studi dari Vincent Greannary yang dikutip oleh World Bank dalam sebuah laporan Pendidikan "Education in Indonesia From Crisis to Recovery" tahun 1988, yang menyebutkan bahwa kemampuan membaca anak-anak kelas VI SD hanya mampu meraih kedudukan paling akhir dengan nilai 51,7 setelah Filipina $(52,6)$, Thailand $(65,1), \quad$ Singapura $(74,0)$, dan Hongkong $(75,5)$

5. United Nations Development Programme (UNDP) menjadikan angka buta huruf dewasa (adult illiteracy rate) sebagai barometer pengukur kualitas suatu bangsa. Hal itu juga berpengaruh pada tinggi rendahnya indeks pembangunan manusia (Human Development Index), dimana menempatkan Indonesia berada pada urutan ke-110 dari 177 negaranegara di dunia (Human Development Report 2005). Beberapa hasil kajian dan laporan UNDP dapat disimpulkan bahwa "kekurang-mampuan anak-anak indonesia dalam bidang matematika dan bidang ilmu pengetahuan, serta tingginya angka buta huruf dewasa karena membaca belum menjadi kebutuhan hidup dan belum menjadi budaya bangsa

6. Konsumsi surat kabar untuk 45 orang (1:45). Di Jawa Barat, buta huruf masyarakatnya mencapai 1,8 juta orang dan Banten 1,4 juta dari 8 juta warganya. idealnya satu surat kabar dibaca oleh 10 orang atau dengan ratio $1: 10$

7. Pikiran Rakyat (19 Januari 2018), menyebutkan bahwa jam bermain anak-anak Indonesia masih tinggi, yakni lebih banyak menghabiskan waktunya untuk menonton acara TV, bermain handphone, bermain playstation. Di Amerika, jam bermain anak-anak dibatasi antara 3-4 jam perhari, sedangkan di Vietnam hanya 1 jam, selebihnya digunakan untuk membaca dan belajar.

\section{Faktor Penyebab}

Ada beberapa alasan minat baca masyarakat di Indonesia dikatakan rendah di antaranya adalah;

a) Rendahnya kemahiran membaca siswa sekolah. Hal tersebut didasarkan atas penelitian Tim Program of International Student Assesment (PISA) Badan Penelitian dan 
Pengembangan Depdiknas yang menunjukkan kemahiran membaca anak usia 15 tahun di Indoensia sangat memprihatinkan. Sekitar 37,6\% hanya bisa membaca tanpa bisa menangkap maknanya; dan $24,8 \%$ hanya bisa mengaitkan teks yang dibaca dengan satu informasi pengetahuan (kompas 2 juli 2003)

b) Sistem pembelajaran di Indonesia belum membuat anak/siswa/mahasiswa harus membaca buku (lebih banyak lebih baik). Biasanya membaca hanya dilakukan di saat mereka akan menghadapi tes/ujian saja, jadi belum ada kesadaran penuh untuk membaca buku

c) Banyaknya jenis hiburan, games, dan tayangan TV yang dapat mengalihkan perhatian anak dan orang dewasa dari buku bacaan.

d) Banyaknya tempat hiburan yang memnghabiskan waktu buat belajar, seperi mall, karaoke, tempat rekreasi, dan play station

e) Budaya baca memang belum pernah diwariskan oleh nenek moyang kita. Nenek moyang kita hanya mengajarkan budaya lisan, tidak ada pembelajaran pengetahuan (sosialisasi) secara tertulis

f) Sarana untuk memperoleh bacaan seperti perpustakaan atau taman bacaan masih merupakan barang aneh dan langka

g) Harga buku relatif masih mahal yang tidak sebanding dengan daya beli masyarakat, sehingga mereka tidak bisa menikmati bacaan secara leluasa di rumahnya.

h) Belum adanya lembaga yang secara formal khusus menangani minat baca.
Sehingga program minat baca hanya dilakukan secara sporadis oleh LSM, organisasi pecinta buku, organisasi penerbit, dan lainnya, yang tidak bisa berkoordinasi walaupun potensi sumber daya ada tetapi belum merupakan kekuatan sinergis yang efektif untuk menumbuhkan minat baca masyarakat Indonesia

i) Minimnya koleksi di perpustakaan serta kondisi perpustakaan yang tidak kondusif bagi tumbuhnya minat baca pengunjung yang memanfaatkan jasa perpustakaan. Duta baca nasional 2006, Tantowi Yahya mengatakan"Masyarakat tidak bisa disalahkan karena rendahnya minat baca, jika kondisi perpustakaan tidak mendukung dan jumlah koleksi buku juga terbatas (Indriani Dyah, Tempointeraktif, Jum'at, 28 Juli 2006).

\section{Upaya Optimalisasi}

Berbagai pernyataan di atas memberikan suatu hipotesis bahwa minat baca masyarakat Indonesia rendah. Untuk itu, perlu diterapkan beberapa strategi untuk menumbuhkan minat baca sejak dini di masyakat, yakni dengan cara:

1) Proses pembelajaran di sekolah harus mengarah pada pembentukan karakter peserta didik untuk rajin membaca dengan memanfaatkan literatur perpustakaan atau sumber belajar lainnya.

2) Menekan harga buku bacaan agar terjangkau oleh daya beli masyarakat

3) Buku bacaan dikemas dengan gambargambar yang menarik. Bahkan seorang penulis Henny Supolo Sitepu 
mengatakan bahwa komik adalah salah satu bentuk bacaan yang bisa menjadi salah satu "pintu masuk"untuk kesenangan anak membaca

4) Menciptakan lingkungan kondusif bagi tumbuhnya minat baca anak-anak, baik dirumah maupun disekolah. Dengan kata lain menumbuhkan minat baca sejak dini. GlenN Dooman dalam bukunya "Mengajar Bayi Anda Membaca" menyebutkan bahwa anak usia 18 bulan hingga 4 tahun memiliki "rasa ingin tahu"yang amat besar

5) Meningkatkan frekuensi pameran buku di setiap kota/kabupaten dengan melibatkan penerbit, LSM, Perpustakaan, Masyara kat, sekolah, dan depdiknas, dengan mewajibkan siswa dan masyarakat untuk berkunjung pada pameran buku tersebut.

6) Di keluarga, orang tua harus memberikan contoh kepada anakanaknya agar gemar memabaca. Berbagai caranya dengan; sediakn waktu luang untuk membaca, sediakan bahan bacaan yang cukup, buatlah waktu membaca dirumah, berikan motivasi, dan biasakan mengajak anak untuk datang ke perpustakaan.

\section{Kegiatan Perpustakaan}

Dalam melaksanakan tugas dan fungsinya, perpustakaan memiliki peran strategis dalam mengembangkan minat baca masyarakat, di antaranya dengan melakukan beberapa kegiatan di bawah ini:

a. Library visit, yaitu kegiatan mengajak masyarakat mengunjungi perpustakaan. Tepatnya pada tanggal 14 september yang ditetapkan Pemerintah sebagai bulan kunjung perpustakaan

b. Book Display, yaitu kegiatan promosi buku baru yang menjadi koleksi terbaru, tujuannya agar masyarakat mengetahui tambahan buku baru yang dilayankan perpustakaan

c. Story Telling, yaitu kegiatan menceritakan sebuah buku pada komunitas atau kelompok tertentu

d. Competition (Writing, Reading, and Searching Information), yaitu mengadakan lomba yang berhubungan dengan perpustakaan, seperti lomba cerita, menulis, menggambar, dan penelusuran informasi dari berbagai sumber search engine di internet

e. Library Exibition, merupakan kegiatan pameran tentang perpustakaan mulai dari administrasi, pengolahan, sampai pelayanan

f. Workshop/Seminar/Diklat, tujuannya agar meningkatkan kompetensi SDM dalam bidang Pusdokinfo (Perpustakaan, Dokumentasi, dan Informasi)

g. Reader Community/Reader Club, membentuk kelompok-kelompok baca yang berhubungan dengan perpustakaan, seperti kelompok pecinta buku

h. Assigment dari guru/dosen, yakni pihak tenaga pengajar mengadakan kerjasama dengan sekolah-sekolah terdekat terkait dengan kewajiban tugas untuk berkunjung keperpustakaan.

i. Reward bagi Kutu Buku, yakni Pihak perpustakaan memberikan penghargaan bagi masyarakat yang rajin membaca 
dan bisa memahami isi bacaan tersebut, bisa berupa hadiah dan penghargaan lainnya.

\section{Manfaat Memiliki Minat Baca}

Minat dan kebiasaan membaca perlu dikembangkan secara terprogram dan terencana. Anak memiliki berbagai potensi yang dapat dan perlu dikembangkan, terutama potensi "ingin tahu”. Anak memang serba ingin tahu, hal ini perlu disalurkan secara positif. Rasa ingin tahu anak dapat dikembangkan melalui buku. Untuk menjadikan anak menyenangi buku perlu dimulai dan dipupuk sejak dini, sejak TK atau masuk SD. Kondisi anak didik saat ini umumnya kurang menyenangi buku, minat baca tidak menonjol, dan mereka lebih suka menonton televisi. Membaca dilakukan terbatas pada buku-buku pelajaran pokok yang digunakan di sekolah. Itu pun bagaikan terpaksa, karena akan diadakan ulangan, atau karena guru memberi pekerjaan rumah.

Ketekunan membaca hanya dimiliki beberapa orang anak saja di sekolah. Akibatnya pengetahuan anak sangat terbatas, penguasaan bahasa menjadi lambat bahkan kemampuan menangkap isi bacaan juga rendah. Ini harus dijadikan suatu tanda dan peringatan bagi guru dan orang tua, bahwa "minat baca" anak harus dipupuk, dikembangkan. Apabila minat baca "tinggi" guru akan lebih mudah dan ringan dalam melaksanakan tugasnya.

Anak-anak akan lebih aktif, mencari dan menggali pengetahuan. Anak akan mengisi sendiri wadah rasa "ingin tahunya". Suasana kelas akan lebih hidup, anak belajar aktif di kelas dan belajar akan lebih mempunyai makna. Menurut seorang ahli, "Katakanlah kepada saya apa bacaan anda, saya akan segera dapat menilai sikap anda". Ungkapan itu bermakna bahwa pribadi seseorang dapat dikenal melalui bacaannya karena bahan bacaan dapat membentuk kepribadian.

Oleh karena itu perlu mengajari anak untuk selektif dalam memilih bacaannya. Dalam memasuki era globalisasi pada saat ini, peran membaca sangat penting dalam kehidupan manusia. Kegiatan membaca diperlukan untuk mencapai kemajuan dan kesuksesan di bidang politik, sosial, ekonomi, dan kebudayaan. Derasnya arus informasi dan komunikasi dewasa ini menyebabkan apa yang kita ketahui hari ini, tentang kemarin, mungkin tadi pagi atau tadi malam telah berubah. Pengembangan minat baca ini perlu ditingkatkan secara berkesinambungan agar terbentuk masyarakat yang berbudaya membaca. Khususnya di Negara ini, cara yang efektif populer untuk memperoleh informasi adalah melalui bacaan. Oleh karena itu sejak dini masyarakat perlu dimotivasi agar senang dan biasa membaca.

Para guru harus mempunyai kemampuan dan kemauan untuk membaca sehingga dalam melaksanakan proses pembelajaran guru tidak hanya mengandalkan ilmu yang pernah dipelajarinya sebelum menjadi guru. Apabila guru menganggap bahwa ilmu yang dimilikinya sudah memadai dan tidak mengikuti perekembangan ilmu itu, maka dapat menimbulkan konflik Antara guru dengan anak didik, karena materi 
yang diajarkan kepada anak didik mungkin sudah "basi".

Hal ini sebenarnya tidak perlu terjadi

bila guru senantiasa mengikuti perkembangan zaman dengan membaca. Sebenarnya tujuan dari pengembangan minat baca ini antara lain untuk:

1. Mendorong minat dan kebiasaan membaca agar tercipta masyarakat yang berbudaya membaca;

2. Meningkatkan layanan perpustakaan;

3. Menciptakan masyarakat informasi yang siap berperan serta dalam semua aspek pembangunan;

4. Memiliki pengetahuan yang terkini, bukan yang sudah "basi";

5. Meningkatkan kemampuan berpikir;

6. dan mengisi waktu luang.

Minat baca dapat ditumbuhkan dan dikembangkan, sehingga menjadi kebiasaan melalui penguasaan teknik membaca yang tepat. Teknik membaca yang tepat dapat membuat membaca lebih efisien, efektif, serta menarik.

\section{METODE PENELITIAN DAN PEMBAHASAN}

\section{Jenis Penelitian}

Pada penelitian ini, peneliti menggunakan jenis penelitian deskriptif dengan pendekatan kualitatif. Penelitian ini bertujuan untuk mengetahui dan mendeskripsikan secara rinci dan mendalam tentang minat baca siswa kelas Sekolah Dasar Negeri 01 Kabupaten Tanah Datar dengan menganalisis berbagai hasil wawancara, tulisan atau catatan yang mengandung informasi tentang minat baca siswa.

\section{Waktu dan Tempat Penelitian}

Penelitian ini dilaksanakan di Sekolah Dasar Negeri 01 Kabupaten Tanah Datar yang beralamatkan di Jalan Jenderal Sudirman, Lima Kaum, Cubadak, Tanah Datar, Kabupaten Tanah Datar, Sumatera Barat 27215. Status akreditasi Sekolah Dasar Negeri 01 Kabupaten Tanah Datar yaitu A. Waktu penyelenggaraan proses pembelajaran dilakukan di pagi hari. Kurikulum yang digunakan saat ini masih menggunakan kurikulum KTSP (Kurikulum Tingkat Satuan Pendidikan).

\section{Subjek Penelitian}

Subjek penelitian dalam penelitian ini adalah Kepala Sekolah Dasar Negeri 01 Kabupaten Tanah Datar, Pustakawan Sekolah Dasar Negeri 01 Kabupaten Tanah Datar, Guru kelas Sekolah Dasar Negeri 01 Kabupaten Tanah Datar, dan Siswa kelas I Sekolah Dasar Negeri 01 Kabupaten Tanah Datar. Dengan masalah yang diteliti adalah minat baca pada siswa kelas I.

\section{Prosedur Penelitian}

Prosedur penelitian menurut Sugiyono (2013: 308) menyatakan penelitian deskriptif kualitatif, pengumpulan data dilakukan pada kondisi alamiah (natural setting). Berdasarkan pernyataan di atas maka teknik pengumpulan data yang digunakan dalam penelitian minat baca siswa kelas I Sekolah Dasar Negeri 01 Kabupaten Tanah Datar menggunakan teknik observasi, wawancara, dan dokumentasi.

1. Observasi Nasution (Sugiyono, 2013: 310) menyatakan bahwa observasi merupakan dasar semua ilmu pengetahuan. Teknik pengumpulan 
data yang digunakan adalah teknik observasi partisipatif pasif, yaitu melakukan pengamatan langsung terhadap subjek dimana sehari-hari mereka berada dan biasa melakukan aktivitasnya, tetapi peneliti tidak ikut terlibat dalam kegiatan tersebut. Observasi dalam penelitian ini dilakukan dengan cara mengamati secara langsung kondisi yang terjadi selama di Sekolah Dasar Negeri 01 Kabupaten Tanah Datar, baik kondisi fisik maupun yang menjadi minat baca siswa selama berlangsungnya penelitian. Peneliti menggunakan alat pengumpul data berupa pedoman observasi dengan tujuan untuk memperoleh data dan informasi yang lengkap. Hal tersebut dilakukan sejak awal penelitian dengan mengamati kondisi fisik, sarana dan prasarana dan lingkungan sekitar Sekolah Dasar Negeri 01 Kabupaten Tanah Datar.

Obyek penelitian dalam penelitian kualitatif yang diobservasi terdiri atas tiga komponen, yaitu:

a) Place, yaitu ruang kelas I Sekolah Dasar Negeri 01 Kabupaten Tanah Datar dan perpustakaan Sekolah Dasar Negeri 01 Kabupaten Tanah Datar.

b) Actor, yaitu Kepala Sekolah Dasar Negeri 01 Kabupaten Tanah Datar, Pustakawan Sekolah Dasar Negeri 01 Kabupaten Tanah Datar, Guru kelas I Sekolah Dasar Negeri 01 Kabupaten Tanah Datar, dan Siswa kelas I Sekolah Dasar Negeri 01 Kabupaten Tanah Datar.

c) Activity, yaitu proses yang meliputi perencanaan dan pelaksanaan mengenai minat baca siswa kelas I
Sekolah Dasar Negeri 01 Kabupaten Tanah Datar.

2. Wawancara Menurut Lexy J. Moleong (dalam Herdiansyah, 2015: 29) wawancara adalah percakapan dengan maksud tertentu yang dilakukan oleh dua pihak, yaitu pewawancara (interviewer) yang mengajukan pertanyaan dan terwawancara (interviewee) yang memberikan jawaban atas pertanyaan itu.

Herdiansyah (2015: 31) menyatakan bahwa wawancara dalam konteks penelitian kualitatif adalah sebuah proses interaksi komunikasi yang dilakukan oleh setidaknya dua orang, atas dasar ketersediaan dan dalam kondisi yang alamiah, dimana arah pembicaraan mengacu kepada tujuan yang telah ditetapkan dengan mengedepankan kepercayaan sebagai landasan utama dalam proses memahami.

Penelitian ini menggunakan teknik pengumpulan data dengan wawancara semi terstruktur. Teknik wawancara semi terstruktur ini digunakan oleh peneliti untuk mempermudah peneliti mendapatkan data yang mendalam dan terperinci dengan mengembangkan pertanyaan tentang minat baca siswa kelas I Sekolah Dasar Negeri 01 Kabupaten Tanah Datar. Wawancara akan dilakukan kepada subyek yang telah ditetapkan yaitu Kepala Sekolah Dasar Negeri 01 Kabupaten Tanah Datar, Pustakawan Sekolah Dasar Negeri 01 Kabupaten Tanah Datar, Guru kelas I Sekolah Dasar Negeri 01 Kabupaten Tanah Datar, dan Siswa kelas I Sekolah Dasar Negeri 01 Kabupaten Tanah Datar. Wawancara dilakukan untuk memperoleh informasi 
secara mendalam tentang apa saja yang menjadi minat baca siswa kelas I Sekolah Dasar Negeri 01 Kabupaten Tanah Datar.

Minat Baca Pada ... (Mega Rohana) 105-4. Dokumentasi dalam penelitian ini, dokumentasi merupakan metode bantu dalam memperoleh data penelitian dilapangan. Dokumentasi diambil dari data-data berupa catatan tertulis maupun peristiwa tertentu yang dapat digunakan untuk mendeskripsikan minat baca siswa kelas I Sekolah Dasar Negeri 01 Kabupaten Tanah Datar. Penggunaan metode ini adalah untuk memperoleh data tertulis mengenai lembaga, dan data yang dapat melengkapi minat baca siswa kelas I Sekolah Dasar Negeri 01 Kabupaten Tanah Datar.

Data pendukung yang akan diperoleh peneliti dalam teknik pengumpulan data dengan dokumentasi dapat berupa foto-foto, dokumen, catatan dan peraturan-peraturan. Data, Intrumen, dan Teknik Pengumpulan Data Pengumpulan data dalam penelitian ini dilakukan secara bertahap sesuai dengan kebutuhan peneliti. Data penelitian ini bersifat deskriptif berupa dokumen pribadi, catatan harian, catatan lapangan, ataupun ucapan responden dari hasil wawancara. Tekhnik yang digunakan adalah observasi, wawancara, dan dokumentasi.

Teknik Analisis Data Miles dan Huberman (Sugiyono, 2011: 246) mengemukakan bahwa aktivitas dalam analisis data kualitatif dilakukan secara interaktif dan berlangsung secara terus menerus sampai tuntas, sehingga diperoleh data akhir. Kesimpulan dalam penelitian kualitatif yang diharapkan adalah menjawab rumusan masalah.

Teknik analisis yang digunakan dalam penelitian ini melalui teknik dan prosedur. Langkah-langkah tersebut adalah mengumpulkan data dengan melalui observasi, wawancara, dan dokumentasi, serta mereduksi data yang diperoleh dari lapangan, membuat sajian data berdasarkan pola-pola hubungan satu data dengan data yang lain, dan menarik kesimpulan.

\section{PEMBAHASAN}

Hasil penelitian wawancara dengan pihak sekolah, yaitu kepala sekolah, bagian perpustakaan, wali kelas dan beberapa siswa kelas I Sekolah Dasar Negeri 01 Kabupaten Tanah Datar, ditemukan minat baca yang masih rendah, rendahnya minat baca disebabkan karena dorongan dari diri sendiri yang masih kurang. Berdasarkan hasil penelitian melalui observasi dan wawancara diperoleh bahwa minat baca adalah keinginan yang disertai usaha-usaha seseorang untuk membaca. Di mana orang yang mempunyai minat membaca yang kuat akan diwujudkan untuk mendapat bahan bacaan sesuai keinginannya. Pembahasan tersebut diperkuat oleh Rahim (2008) yang menjelaskan bahwa minat baca ialah keinginan yang kuat disertai usaha-usaha seseorang untuk membaca. Minat baca siswa kelas I Sekolah Dasar Negeri 01 Kabupaten Tanah Datar masih rendah. Dilihat dari tingkat kunjungan siswa ke perpustakaan yang jarang dilakukan. Para siswa lebih memilih di kelas, bercerita dengan teman, 
dibandingkan dengan membaca buku ke perpustakaan. Rendahnya minat baca siswa disebabkan siswa kurang memiliki perasaan, perhatian terhadap buku dan manfaat membaca. Kondisi ini dapat terdapat pada siswa kelas I Keadaan tersebut disebabkan karena kesadaran untuk membaca masih rendah, kelas I setiap harinya difokuskan untuk mengeja, berhitung, dan lebih suka bermain bercerita dengan teman sekelasnya sehingga jam untuk berkunjung ke perpustakaan kurang sekali.

Kenyataan tersebut diperjelas oleh petugas perpustakaan yang menjelaskan bahwa: "siswa kelas I jarang berkunjung keperpustakaan karena di kelasnya sering bermain dan lebih senang bercerita dengan teman sekelasnya", namun para siswa tidak memperhatikan dampak yang bermanfaat jika benar-benar membiasakan membaca. Kurangnya motivasi yang diberikan dari pihak sekolah maupun orang tua itulah, siswa kelas I tidak mengetahui pentingnya perpustakaan.

Perpustakaan bukan hanya untuk mengumpulkan dan menyimpan bukubuku, tetapi dengan adanya penyelenggaraan perpustakaan sekolah diharapkan dapat membantu siswa dan guru menyelesaikan tugastugas dalam proses pembelajaran. Ketersediaan buku yang cukup memadai dan menarik dapat mendukung timbuhnya minat siswa untuk membaca. Selain itu, pihak sekolah harus dapat menentukan kondisi belajar yang kondusif, sehingga minat membaca siswa akan meningkat. Kondisi yang kondusif akan cepat tercapai jika didukung adanya pengembangan, baik untuk perangkat lunak, yaitu dengan cara di perpustakaan dibuat sistem komputerisasi, sehingga mempermudah siswa untuk mencari buku yang dinginkan.

Cara ini mungkin dapat meningkatkan minat baca siswa, karena siswa akan terbawa perasaannya jika apa yang dilihat lebih menarik dan menyenangkan, sehingga lama kelamaan akan tertarik untuk membaca buku. Disamping mudah mencari judul buku, fasilitas lain sudah lebih modern, sehingga siswa lebih tertarik untuk berkunjung ke perpustakaan dan akhirnya mulai untuk membaca buku yang tersedia tersebut.

Sedangkan faktor-faktor yang mempengaruhi minat baca siswa Sekolah Dasar Negeri 01 Kabupaten Tanah Datar selama ini dipengaruhi oleh beberapa faktor yaitu: faktor internal (perasaan, perhatian dan motivasi), sedangkan faktor yang mempengaruhi dari luar teridiri dari peranan guru, lingkungan, keluarga dan fasilitas. Faktor-faktor yang mempengaruhi tersebut dapat dijelaskan sesuai dengan teori yang mengatakan bahwa minat baca siswa yaitu dipengaruhi oleh faktor dari dalam diri siswa (internal) yang meliputi perhatian, perasaan, dan motivasi, kemudian faktor dari luar siswa (eksternal) yang meliputi peranan guru, lingkungan, keluarga, dan fasilitas. dan faktor lingkungan (di sekolah). Hasil penelitian ini faktor-faktor yang mempengaruhi minat baca siswa kelas Sekolah Dasar Negeri 01 Kabupaten Tanah Datar yang berasal dari faktor internal adalah perasaan yang dimiliki tiap siswa berbedabeda, sehingga untuk menyatukan perasaan yang berbeda-beda itulah maka, peneliti yang bekerjasama dengan pihak sekolah. 
Langkah yang dilakukan adalah dengan cara memberi motivasi, perhatian secara terus menerus kepada siswa kelas I dan perhatian untuk meningkatkan minat baca. Perhatian yang dilakukan peneliti adalah dengan cara penyelami keinginan para siswa, untuk mengetahui pentingnya membaca. Minat Baca disosialisasikan untuk mengetahui keinginan dan memotivasi siswa agar siswa menyadari bagaimana pentingnya membaca. Manfaatnya selain menambah ilmu, membaca juga dapat membuka wawasan yang lebih luas lagi serta dapat menambah pengetahuan yang lebih baik lagi. Penjelasan tersebut dapat dipertegas sesuai dengan teori yang dikemukakan oleh Rahim (2008). Faktor dari dalam diri meliputi perhatian, perasaan, dan motivasi. Perasaan senang terhadap bacaan merupakan ekspresi seseorang terhadap bacaan. Hal tersebut dapat berupa jenis buku bacaan yang disenangi.

Hal tersebut dikarenakan terdapat unsur perhatian dan motivasi seseorang terhadap bacaan tersebut. Motivasilah yang mendorong siswa ingin melakukan kegiatan membaca. Seseorang siswa yang gemar membaca, maka tidak perlu disuruh-suruh untuk membaca, karena membaca tidak hanya menjadi aktifitas kesenangannya, tapi sudah menjadi kebutuhan. Untuk mendapat hasil membaca yang baik, maka siswa harus mempunyai perhatian terhadap bahan bacaannya, jika bahan bacaannya tidak menjadi perhatian siswa, maka timbullah kebosanan. Agar siswa dapat membaca dengan baik, usahakanlah bahan bacaan selalu menarik perhatian.
Hal tersebut sesuai dengan yang dikatakan oleh Herman Wahadaniah (1997: 16) yang menyatakan minat baca adalah suatu perhatian yang kuat dan mendalam disertai dengan perasaan senang terhadap kegiatan membaca sehingga dapat mengarahkan seseorang untuk membaca dengan kemauannya sendiri atau dorongan dari luar. Disampung faktor dari diri siswa, faktor lain yang mempengaruhi minat baca adalah tingkat pendidikan dan pendapatan orang tua. Faktor dari orang tua yang memiliki tingkat pendidikan tinggi dan faktor ekonomi yang mapan, terlihat anaknya akan terlihat minat bacanya lebih bagus dibandingkan dengan pendapatan orang tua kurang mapan dan pendidikan kurang memadai.

Kondisi ini dapat dijumpai pada siswa kelas I Sekolah Dasar Negeri 01 Kabupaten Tanah Datar. Siswa yang berasal dari keluarga yang mampu terlihat lebih serius dalam membaca, tetapi jika siswa yang berasal dari keturunan keluarga yang kurang mampu, anak kelihatan malas-malasa (minat bacanya kurang sekali). Faktor inilah yang sangat berpengaruh terhadap minat baca siswa yang ada di Sekolah Dasar Negeri 01 Kabupaten Tanah Datar selama ini. Hasil penelitian dari faktor yang mempengaruhi minat baca siswa selanjutnya adalah adanya peran guru dalam pembelajaran di kelas, faktor yang dipengaruhi oleh metode pembelajaran yang digunakan di kelas, dan faktor yang dipengaruhi oleh aspek perpustakaan. Faktor tersebut ini di Sekolah Dasar Negeri 01 Kabupaten Tanah Datar peran guru masih kurang maksimal, sehingga siswa akan menolak 
perintah guru karena guru kurang memperhatikan keinginan siswanya. Seorang guru hendaknya menggunakan teori atau komponen strategi pembelajaran sebagai prinsip pembelajaran. Secara khas, strategi pembelajaran berinteraksi dengan situasi belajar.

Situasi-situasi belajar ini sering dinyatakan dalam model-model pembelajaran. Sehingga dalam proses pembelajaran dapat diterima oleh siswanya dengan baik dan lebih mudah, terutama dalam meningkatkan minat baca siswa yang selama ini masih rendah. Model pembelajaran maupun strategi pembelajaran yang diperlukan untuk mengaplikasikannya berbeda-beda tergantung pada situasi belajar, sifat materi dan jenis belajar yang diinginkan (Tennyson, dan Posey, 1992).

Selain menerapkan strategi pembelajaran, pemanfaatan untuk aktivitas menggunakan proses dan sumber untuk belajar. Pihak guru yang terlibat dalam pemanfaatan mempunyai tanggungjawab untuk mencocokkan para siswa dengan bahan dan aktivitas yang spesifik, menyiapkan mental siswa agar dapat berinteraksi dengan bahan dan aktivitas yang dipilih, memberikan bimbingan selama kegiatan berlangsung, memberikan penilaian atas hasil yang dicapai siswa berprestasi, sehingga dapat memotivasi siswa yang lain untuk mendapatkan prestasi. Karena keberhasilan (prestasi sekolah) tidak mudah didaptkan jika tidak diikuti kerja keras dan minat yang tinggi, yaitu minat untuk belajar, minat membaca serta minat mencapai keberhasilan sesuai fungsi pemanfaatan. Fungsi pemanfaatan penting karena membicarakan kaitan siswa dalam belajar dengan bahan atau sistem pembelajaran. Jelas fungsi ini sangat kritis karena penggunaan oleh siswa kelas I Sekolah Dasar Negeri 01 Kabupaten Tanah Datar yang mana minat baca siswanya masih rendah. Minat bacanya yang masih rendah ini maka fungsi pemanfaatan ini harus memiliki jangkauan aktivitas dan strategi mengajar yang luas untuk meningkatkan minat siswanya.

Peran guru merupakan faktor yang mempengaruhi minat baca siswa. Guru merupakan orang tua kedua bagi siswa. Guru dapat membantu siswanya mengembangkan ilmu pengetahuan untuk masa depannya. Salah satu peran guru dalam proses pembelajaran adalah sebagai motivator. Peran guru tersebut yaitu pemberian motivasi agar mau membaca. Peranan guru sebagai motivator ini penting artinya dalam meningkatkan pengembangan kegiatan membaca siswa. Faktor guru yang berupa kemampuan mengelola kegiatan dan interaksi belajar mengajar, khususnya dalam program pengajaran membaca.

Guru yang baik harus mengetahui karakteristik dan minat anak. Guru bisa menyajikan bahan bacaan yang menarik teori Dawson dan Bamman (dalam Santoso, 2005). Guru harus dapat merangsang dan memberikan dorongan untuk memunculkan potensi siswa dalam hal membaca. Salah satu cara untuk memotivasi siswa dalam belajar adalah membangkitkan minat siswa. Karena itu upaya peningkatan minat dan kebiasaan membaca juga diadakan di sekolah melalui keberadaan perpustakaan. Aspek perpustakaan merupakan faktor yang 
mempengaruhi minat baca siswa. Perpustakaan sebagai sumber belajar yang diharapkan dapat menumbuhkan minat baca bagi siswa, maka hendaklah dikelola secara baik, misalnya sistem komputerisasi yang dapat memudahkan siswa dalam mencari judul buku yang diinginkan. Perpustakaan yang baik harus bisa memberikan suasana yang nyaman dengan selalu menjaga kebersihan, menjaga kerapian buku, serta penataan tempat baca yang bisa membuat siswa nyaman untuk berlama-lama di perpustakaan. Suasana yang nyaman dapat menarik minat siswa untuk membaca ke perpustakaan.

\section{KESIMPULAN DAN SARAN}

Sebagai penutup bahwa pada dasarnya pengentasan minat baca masyarakat harus dilakukan secara simultan oleh berbagai pihak yang dilakukan secara berkesinambungan agar membuahkan hasil yang optimal sesuai dengan harapan bersama. Budaya baca adalah kegiatan yang hendaknya jadi prioritas utama pemerintah dalam meningkatkan kecerdasan bangsa. Dengan bantuan perpustakaan dan semua elemen masyarakat, kita bisa membangun pusat informasi dan pengetahuan melalui peradaban literasi di masyarakat indonesia. Minat baca diharapkan mampu meningkatkan semagat baca dan memaksa pemerintah meningatkan sarana dan prasaran dalam meningkatkan koleksi yang ada di perpustakaan. Dengan pemerintah bersinergi bersama sekolah dan lingkungan keluarga akan dapat meningkatkan minat baca itu sendiri.

\section{DAFTAR RUJUKAN}

http://regional.kompas.com/read/2015/05/ 25/17565591/Yayuk.Basuki.Minat. Baca.Anak.Indonesia.Hanya.0.01.Pe $\underline{\text { rsen }}$

Nur Triatma, 2016. Minat Baca Pada Siswa Kelas VI Sekolah Dasar Negeri Delegan 2 Prambanan Sleman Yogyakarta. E-Jurnal Prodi Teknologi Pendidikan Vol. V Nomor 6 Tahun 2016. UNY : Yogyakarta.

Mirwan. 2016.

UNIMED:

http://digilib.unimed.ac.id/6670/11/9 $\% 20$ NIM.1123311086\%20CHAPT

ER\%20I.pdf

Yuventia, yuniwati. "Melalui Budaya Baca Membangun Perpustakaan Sebagai Culture Preservation". Buletin Pustaka, Ed.5 Th II, Maret 2010.

Karyono, Hari. "Menumbuhkan Minat Baca Sejak Usia Dini”. Warta PNFI, Vol.78, Edisi XI tahun 2009. 